\title{
DESIGN PARAMETERS ASSESSMENT FOR GROUND ANCHORS IN TERTIERY FLUVIAL CLAYS
}

\author{
Jan ŠTEFAŇÁK, Lumír MIČA \\ Department of Geotechnics, Faculty of Civil Engineering, Brno University of Technology, \\ Veveri 331/95, 602 00, Brno, Czech Republic
}

Received 16 June 2014; accepted 07 November 2014

\begin{abstract}
The design of the bond length of an postgrouted presstressed anchor is based on presumption of bond shear stress on contact of the bond skin and surrounding soil. Statistical analysis of measured test data was performed, including Latin Hypercube Sampling technique, to specify shear stress parameter for geotechnical conditions of Neogene fluvial clays stiff to very stiff consistency. Information about anchors installed into clays was abstracted from acceptance tests records provided by TOPGEO - Czech special foundations contractor. All tested anchors were used as supports of temporary retaining structures on construction site in Olomouc, Czech Republic. Results of conducted analysis are expressed as confidence interval estimation of mean of bond shear stress parameter. This parameter is usable for future design of anchors installed into analogical geotechnical conditions. Influencing of results by technological aspects of the construction process is partially discussed too.
\end{abstract}

Keywords: ground anchors, design of anchoring, bond shear stress, statistical methods, Latine Hypercube Sampling, Lognormal distribution.

\section{Introduction}

A postgrouted prestressed ground anchor is a structural element installed in soil or rock that is used to transmit an applied tensile load into ground. The ground anchors are typically used for supporting of temporary or permanent retaining structures during deep excavations, or for the supporting of anchored walls used to stabilize slopes in highway projects. The ground anchors are also used to stabilize structures against the effects of lifting, shifting or overturning (Xanthakos 1991).

Wide range of design approaches is being used for establish the load carrying capacity of anchors. The design assumptions of uniform load distribution along the bond area are generally adopted on a worldwide scale for design of ground anchors (Kramer 1978; Jones, Turner 1980; Litteljohn 1980).
Each working anchor shall be subjected to the Acceptance test according to ČSN EN 1537 (2001). The records describing the processes of testing have to be kept. Each working anchor provides thus a full and comprehensive set of data from the installation and testing. Thus databases of these records are created by construction contractors. Afterwards analysis of these databases can afford information about behaviour of anchors installed in specific soil conditions.

Data from Acceptance tests records executed on construction site in Olomouc, Czech Republic are analysed in this paper. Statistical methods are used to assess a bond shear stress parameter. This parameter can be used for future design of ground anchors for construction sites in near localities or for anchors placed in soil with the same properties generally. 


\section{Geological and geotechnical conditions}

The bedrock of the monitored area consists of the Western Carpathian zone rocks of Tertiary age, represented by Miocene calcareous clays and sands (Baden, Moravia).

Geological survey found 4.2 to $5.2 \mathrm{~m}$ thick layers of backfill consisting of sandy soil, loamy soil with sand, loam, sandy backfill with soil and sand with clay and backfill soft to stiff consistency with various contents of rubble and debris to a maximum size $80 \mathrm{~mm}$. Fluvial sediments were encountered in the subsoil strata. Clayey gravel occurred to a depth of $4.8 \mathrm{~m}$ in some profiles (Balšínková, Hauser 2010).

The neogene fluvial clays, stiff (to very stiff) consistency according to ČSN EN ISO 14688-2 (2004), were deposited furthermore (Which is crucial soil type for purposes of conducted analysis, because all bonds of investigated anchors were located in these clays. Properties of soils deposited in typical geological profile are summarized in Table 1.

Table 1. Properties of soils (Balšínková, Hauser 2010)

\begin{tabular}{|l|c|c|c|}
\hline \multicolumn{1}{|c|}{ Geotechnical soil type } & 0.1 & 0.2 & 0.3 \\
\hline ČSN EN ISO $14688-2$ & $\mathrm{saSi}$ & $\mathrm{saclSi}$ & $\mathrm{Cl}$ \\
\hline Density $\gamma\left[\mathrm{kNm}^{-3}\right]$ & 18.0 & 18.5 & 20.5 \\
\hline Water content $w[\%]$ & - & - & 34.53 \\
\hline Liquidity limit $w_{L}[\%]$ & - & - & 77.1 \\
\hline Plasticity limit $w_{P}[\%]$ & - & - & 25.52 \\
\hline Plasticity index $I_{P}[-]$ & - & - & 51.85 \\
\hline Consistency index $I_{C}[-]$ & - & - & 0.83 \\
\hline$\varphi^{\prime}\left[{ }^{\circ}\right]$ & 25 & 23 & 15 \\
\hline$c^{\prime}[\mathrm{kPa}]$ & 14 & 16 & 5 \\
\hline E $[\mathrm{MPa}]$ & 6 & 4 & 3 \\
\hline$v[-]$ & 0.35 & 0.35 & 0.42 \\
\hline
\end{tabular}

Note: Only properties of sample 0.3 are the results of laboratory testing. The properties of soil types 0.1 and 0.2 were estimated by geologist.

The dynamic probing (DPH type of test) according to ČSN EN ISO 22476-2 (2005) was conducted. Configuration of dynamic probing equipment was:

- Force of a slight hammer was $500 \mathrm{~N}$;

- Height of fall of the hammer was $500 \mathrm{~mm}$;

- Diameter of the cone tip was $43.7 \mathrm{~mm}$;

- Cone tip apex angle was $90^{\circ}$;

- The $\mathrm{N}_{10}$-value was recorded for every $100 \mathrm{~mm}$ of penetration depth.

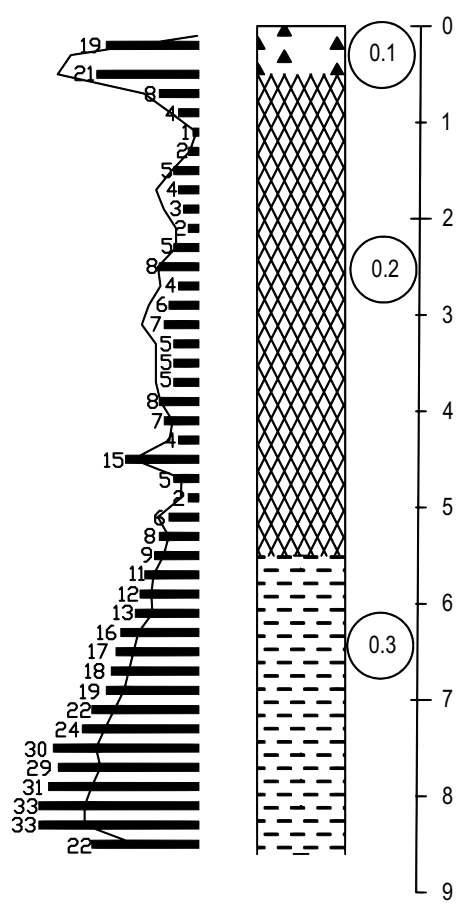

Fig. 1. Typical geological profile with $N_{10}$ record: 0.1 - Loamy soil with sand; 0.2 - Backfill soft to stiff consistency; 0.3 - Neogene fluvial clays

The example of typical geological profile with blow counts record is shown in Figure 1.

\section{System of data mining}

The Acceptance tests of ground anchors are associated with initial stressing operations. Objectives of these tests are to demonstrate that a proof load can be sustained by the anchor, to determine the apparent tendon free length and to ensure that the lock-off load is at the designed load level. Each working anchor provides thus a full and comprehensive set of data from the installation and testing with regard to its elastic and nonelastic behaviour and bond capacity. Sketch of typical ground anchor parts is shown in Figure 2.

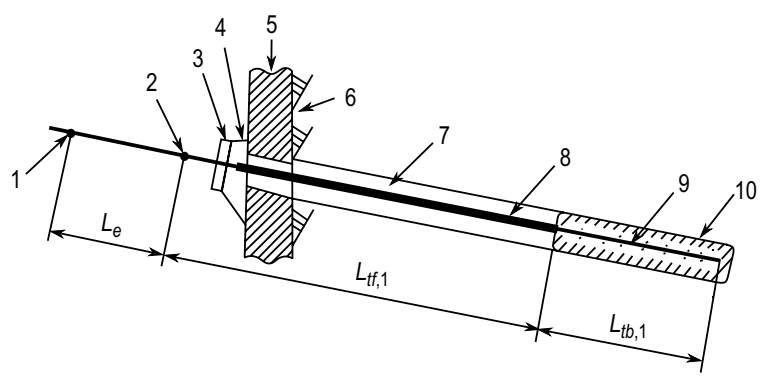

Fig. 2. Sketch of a ground anchor: 1- Anchorage point at jack during stressing; 2 - Anchorage point at anchor head in service; 3 - Bearing plate; 4 - Load transfer black; 5 - Structural element; 6 - Soil; 7 - Borehole; 8 - Debonding sleeve; 9 - Tendon; 10 Grout body; $L_{t f, 1}-$ Tendon free length; $L_{t b, 1}-$ Tendon bond length; $L_{e}-$ External length of tendon 
Next information about dimensions of anchor, material parameters and applied forces were obtained from Acceptance test records and drilling reports:

$L_{t f, 1}$ - Tendon free length (length of tendon between the anchor head and the proximal end of the tendon bond length) prescribed by design (see Fig. 2).

$L_{t b, 1}$ - Tendon bond length (length of the tendon that is bonded directly on the grout and capable of transmitting the applied tensile load) prescribed by design (see Fig. 2).

$L_{e}$ - External length of tendon (measured from the tendon anchorage in the anchor head to the anchorage point in the stressing jack) (see Fig. 2).

$N$ - Number of strands in multi strand tendon.

$\Phi_{1}$ - Diameter of one strand.

$A_{1}$ - Cross-sectional area of one strand.

$E$ - Elastic modulus of anchor tendon.

$d$-Diameter of borehole depending on auger dimensions.

$P_{P}$ - Proof load.

$P_{A}$ - Datum load.

$\Delta_{L, m}$ - Measured elastic extension of anchor tendon under load increment $\Delta P_{P}$.

Two types of the ground anchors were used in analysed case. Parameters describing geometrical and mechanical properties of those anchors are summarized in Table 2.

Table 2. Geometrical and mechanical properties of analyzed ground anchors

\begin{tabular}{|c|c|c|c|}
\hline Sample & A_240/5 & B_480/9 & \\
\hline$L_{t f, 1}$ & 4 & 6 & {$[\mathrm{~m}]$} \\
\hline$L_{t b, 1}$ & 5 & 9 & {$[\mathrm{~m}]$} \\
\hline$L_{e}$ & 0.5 & 0.5 & {$[\mathrm{~m}]$} \\
\hline$\Phi_{1}$ & 15.5 & 15.5 & {$[\mathrm{~mm}]$} \\
\hline$A_{1}$ & 140 & 140 & {$\left[\mathrm{~mm}^{2}\right]$} \\
\hline$n$ & 3 & 4 & {$[\mathrm{pcs}]$} \\
\hline$d$ & 187 & 187 & {$[\mathrm{~mm}]$} \\
\hline$E$ & 195 & 195 & {$[\mathrm{GPa}]$} \\
\hline$P_{p}$ & 240 & 480 & {$[\mathrm{kN}]$} \\
\hline
\end{tabular}

\section{Initial data processing}

Initial data processing consisted of calculating Apparent free length according to ČSN EN 1537 (2001) in the first step and Apparent free length criteria checking. The dimensions arisen during stressing operations, and the bond stress along the tendon bond length were determined in next steps (Štefaňák 2013):
- Cross-sectional area of multi strand tendon was calculated as

$$
A=A_{1}^{*} n \text {. }
$$

- Tendon free length $L_{t f, 2}$ (length of tendon between the anchor head and the proximal end of the tendon bond length) depending on measured elastic extension $\Delta_{L, m}$ was determined. The value is equivalent to the length of the tendon that with the proof load minus alignment load over its length would elongate the same amount as measured in the test. $L_{t f, 2}$ is equal to Apparent free length according to ČSN EN 1537 (2001).

$$
L_{t f, 2}=L_{a p p}=\frac{A^{\star} E^{\star} \Delta_{L, m}}{\left(P_{P}-P_{A}\right)} .
$$

- Apparent free length criteria $L_{a p p \text {,min }} a_{L a p p \text {, max }}$ were checked. Where the Apparent tendon free length lay outside the limits, the anchor was excluded from analysis.

$$
\begin{gathered}
L_{a p p, \min }=0.8^{\star} L_{t f, 1}+L_{e} . \\
L_{a p p, \max }=\max \left\{\begin{array}{l}
\left(L_{t f, 1}+L_{e}+0.5^{\star} L_{t b, 1}\right) ; \\
\left(1,1^{\star} L_{t f, 1}+L_{e}\right)
\end{array}\right\} . \\
L_{a p p, \min } \leq L_{a p p} \leq L_{a p p, \max } .
\end{gathered}
$$

- Tendon bond length $L_{t b, 2}$ (length of tendon between the anchor head and the proximal end of the tendon bond length) observed during stressing was determined.

$$
L_{t b, 2}=L_{t f, 1}+L_{t b, 1}-L_{f t, 2} .
$$

\section{Statistical data processing}

The Acceptance test was considered a random experiment with random variable - bond shear stress. A Random experiment is an experiment that can be repeated numerous times under the same conditions. The outcome of an individual random experiment must be independent - it must in no way be affected by any previous outcome and cannot be predicted with certainty. These requirements were accomplished due to:

- All tested anchors were installed in the soil with identical physical parameters;

- Stressing operations were conducted by using the same stressing tools for each anchor;

- Measuring of extension of anchor tendon was performed by using the same calibrated gauge for each anchor; 
- Each anchor from the same random selection had the identical design dimensions and was tested on the identical level of Proof testing load.

\subsection{Theoretical probability distribution}

In the case of soil properties, a normal distribution often already shows an adequate compliance. For soil parameters, which show typically a large scatterings (it means those with value of coefficient of variation $\mathrm{CoV}=S / \bar{X}>0,3)$ the lognormal distribution is preferable (Pohl 2011). The normal distribution (or Gaussian) of $\Delta_{L, m}$ (measured elastic extension of anchor tendon under load increment $\Delta P_{P}$ ) was presupposed first.

The normal distribution $N\left(\mu, \sigma^{2}\right)$ is a continuous probability distribution described by parameters $\mu$ and $\sigma^{2}$. It is defined by the probability density function (PDF) (Likeš, Machek 1981):

$$
f_{(x)}=\frac{1}{\sigma \sqrt{2 \pi}} e^{-\frac{(x-\mu)^{2}}{2 \sigma^{2}}} .
$$

The parameter $\mu$ is the mean of the distribution and the parameter $\sigma^{2}$ is its variance. The sample variance $\bar{X}$ was used as an estimator of the mean $\mu$.

The cumulative distribution function (CDF) of the normal distribution is the integral

$$
F_{(x)}=\int_{-\infty}^{x} \frac{1}{\sigma \sqrt{2 \pi}} e^{-\frac{(x-\mu)^{2}}{2 \sigma^{2}}} d t .
$$

The Lognormal distribution $\ln N\left(\mu, \sigma^{2}\right)$ is a continuous probability distribution of random variable, whose logarithm is normally distributed. Distribution is described by parameters $\lambda$ and $\zeta$. It is defined by the probability density function (PDF)

$$
\begin{aligned}
& f_{x}(x ; \lambda ; \zeta)=\frac{1}{x \zeta \sqrt{2 \pi}} e^{-\frac{(\ln x-\lambda)^{2}}{2 \zeta^{2}}}, \\
& 0<x<\infty ; 0<\lambda<\infty ; \zeta^{2}>0 .
\end{aligned}
$$

The mean $\mu$ of this distribution is then expressed as

$$
\mu=e^{\lambda+\frac{\zeta^{2}}{2}} .
$$

And the variance $\sigma^{2}$ is

$$
\sigma^{2}=\left(e^{\zeta^{2}}-1\right) e^{2 \lambda+\zeta^{2}}
$$

Thus, if the random variable $X$ is lognormally distributed, then $Y=\log (X)$.

\subsection{Test of goodness of fit}

The Anderson-Darling test is a statistical test of whether a given sample of data is drawn from a given probability distribution. The Anderson-Darling (AD) test was used to decide if a data in samples of $\Delta_{L, m}$ values (measured elastic extension of anchor tendon under load increment $\Delta P_{P}$ ) comes from a population with a normal distribution. The two hypotheses for the Anderson-Darling test for the normal distribution are given below:

H0: The data follow the normal distribution;

H1: The data do not follow the normal distribution.

The Anderson-Darling statistic was given by the formula:

$$
\begin{aligned}
& A D=-n-\frac{1}{n} \sum_{i=1}^{n}(2 i-1)^{\star} \\
& {\left[\ln F\left(X_{i}\right)+\ln \left(1-F\left(X_{n-i+1}\right)\right)\right],}
\end{aligned}
$$

where $n$ is sample size, $F(X)$ is cumulative distribution function for the normal distribution and $i$ is the $\mathrm{i}^{\text {th }}$ sample, when the data is sorted in ascending order. The adjusted value of statistic is given by:

$$
A D^{\star}=A D\left(1+\frac{0.75}{n}+\frac{2.25}{n^{2}}\right) .
$$

P-value for adjusted AD statistic was possible to determine and use to conclude, if the test was significant in case of this study. The p-value is the probability of getting a more extreme result if the null hypothesis is true. If the p-value was higher than the significance level $\alpha=0.05$, the null hypothesis was accepted. There are different equations for calculation p-value depending on the value of $\mathrm{AD}^{\star}$ ( $\mathrm{D}^{\prime}$ Agostino, Stephens 1986).

$\mathrm{AD}$ test for the Lognormal distribution was implemented by transforming the data using a logarithm and using above test for normality.

\subsection{Transformation of random variables}

The situation arises in the case of determining the shear stress parameter $\tau$, where it is necessary to assign the probability distribution to the random variable $Y$ (bond shear stress parameter $\tau$ ), which is a function of the random variable $X$ (measured elastic extension of anchor tendon $\Delta_{L, m}$ under the load increment $\Delta P_{P}$ ), whose probability distribution is known:

$$
Y=h(X),
$$

where $h$ is a real function of one real variable defined on the field of values of a random variable $X$. It can be 
said, that the random variable $Y$ is transformation of random variable $X$ (Vořechovský et al. 2012).

The distribution function of the random variable $X$ is necessary to express in the first step. It was verified that random sample $X$ comes from a Lognormal distribution by the Test of goodness of fit. The Cumulative distributiom function (CDF) of the Lognormal distribution has the form:

$$
\begin{aligned}
& X \sim F_{X}(X)= \\
& P(X \leq x)=f_{x}(x ; \lambda ; \zeta)=\frac{1}{x \zeta \sqrt{2 \pi}} e^{-\frac{(\ln x-\lambda)^{2}}{2 \zeta^{2}}} d t \\
& 0<x<\infty ; 0<\lambda<\infty ; \zeta^{2}>0 .
\end{aligned}
$$

The probability in equation (18) is then expressed using the definition of cumulative distribution function $(\mathrm{CDF})$ of the random variable $Y$ :

$$
F_{Y}(y)=P(Y \leq y),
$$

by means of a random variable $X$ :

$$
Y \sim F_{Y}(y)=P(h(X) \leq y) .
$$

Probability density function (PDF) of the random variable $\mathrm{Y}$ is then expressed using derivation of $F_{Y}(y)$

$$
Y \sim f_{Y}(y)=\frac{d}{d_{y}} F_{Y}(y)
$$

The mean $\mu$ of (PDF) of random variable $Y$ is

$$
E[Y]=\mu_{y}=\int_{-\infty}^{\infty} y f_{Y}(y) d_{y} .
$$

And the variance

$$
D[Y]=\sigma^{2}=E\left[Y^{2}\right]-(E[Y])^{2},
$$

where

$$
E\left[Y^{2}\right]=\int_{-\infty}^{\infty} y^{2} f_{Y}(y) d_{y} .
$$

The transformation function is expressed by formula

$$
\begin{aligned}
& h(X)=\frac{P_{P}}{\left(\pi^{\star} d^{\star} L_{t b, 2}\right)}= \\
& \frac{P_{P}}{\left[\pi^{\star} d^{\star}\left(L_{t f, 1}+L_{t b, 1}-L_{t f, 2}\right)\right]}= \\
& \frac{P_{P}}{\left\{\left[\pi^{\star} d^{\star}\left(L t f, 1+L t b, 1-\left(\frac{A^{\star} E^{\star} X}{P_{P}-P_{A}}\right)\right)\right]\right\}},
\end{aligned}
$$

in this specific example focused on determination of the bond shear stress. Simulation methods such as Monte Carlo or variance reduction techniques such as LHS method can be advantageously used to accelerate and facilitate the transformation and to calculation of statistical moments of PDF assigned to random variables $Y$ (shear stress $\tau$ ) (Baecher 2003).

\subsection{Statistical processing using simulation methods}

A random variable $X\left(\Delta_{L, m}\right.$, or the information about its probability distribution and moments characteristics of the distribution calculated in the previous paragraphs respectively) serves as the random input for further processing, which consists of the following steps:

- Defining the transformation function $Y=h(X)$;

- Calculating realization of function $Y=h(X)$ for all generated realizations vector $X\left(\Delta_{L, m}\right)$;

- Assigning the most suitable probability distribution to the set of data consists of the realizations of the function $Y=h(X)$ (One dimensional vector $Y(\tau)$ and calculating its statistical central moments).

Latin Hypercube Sampling technique (LHS) was used for generating realizations of one-dimensional vector $X\left(\Delta_{L, m}\right)$. The advantage of this method is that it requires less number of simulations while conserving significance estimates of statistical parameters usually (Novák et al. 2012a). Principle of generating a random variable using inverse transformation of the distribution function is depicted in Figure 3 and Figure 4.

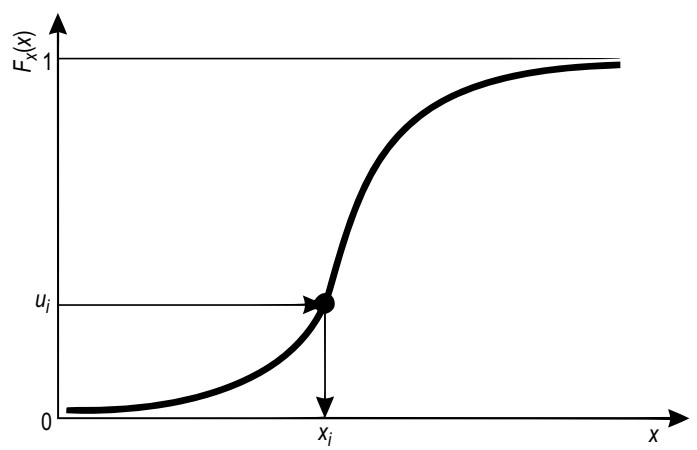

Fig. 3. Principle of inverse transformation of CDF in Monte Carlo method, Sadílek et al. (2011)

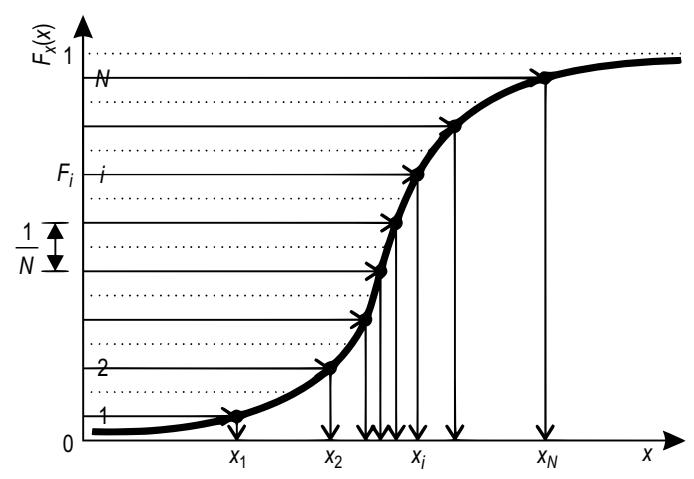

Fig. 4. Principle of inverse transformation of CDF in LHS method. Sadílek et al. (2011) 


\subsection{Confidence interval estimation for the mean}

The arithmetic probability for a worse value should not exceed $5 \%$ in the regarded limit state if statistical methods are applied, with regard to ČSN EN 1990 (2004) (sed. 2.4.5.2 (11)). Cautious estimation of the mean of a limited set of geotechnical parameters corresponds to a mean with a confidence level of $95 \%$ in this context. Corresponding value of significance level is $\alpha=0.05$.

Hence, $100(1-\alpha)$ confidence interval for a mean is a range where the interval would include the true value $100(1-\alpha)$ of the time (Koutková 2004).

$\left\langle\bar{X}-t\left(n-1 ; 1-\alpha_{1}\right) \frac{S}{\sqrt{n}}, \bar{X}+t\left(n-1 ; 1-\alpha_{1}\right) \frac{S}{\sqrt{n}}\right\rangle$,

where $\alpha_{1}=\alpha_{2}=\alpha / 2$ is the significance level, $n$ is sample size, and $t$ is the quantil of Student's t-distribution

$$
t\left(n-1 ; 1-\alpha_{1}\right) \text {. }
$$

\section{Statistical processing using FReET}

Software tool Freet was used for purposes described in paragraphs 4.1-4.5 (Novák et al. 2012b; Vořechovský et al. 2012).

The procedure of statistical data processing of measured values described in previous paragraphs can be done "manually", partially automated using a spreadsheet editor, or one of the commercial packages of statistical software can be used. Analysis in this paper was conducted using software Freet (Novák et al. 2012a). Processing becomes more efficient using this tool, especially when there is a large amount of data to be analysed.

Software options allows the evaluation of the set of measured data in the form of the test of goodness of fit, followed by assigning the most appropriate probability distribution to the data and calculating its central moments (e.g. mean, variation, $\mathrm{CoV}$ etc.). These operations were carried out for both types of anchors described in the Table 2.

\section{Results}

Partial results of statistical analysis described above (theoretical probability distribution assigned to the random variable $\left.X\left(\Delta_{L, m}\right)\right)$ are summarized in Table 3 . Data comes from Lognormal probability distribution, based on the Test of goodness of fit.

The Lognormal probability distribution was fitted to the set of data $Y(\tau)$, obtained as a result from the LHS simulation method, also. Graphical outputs of the analysis see in Figure 5 and Figure 6. Values of search bond shear stress $\tau$ (Moments describing its distribution, respectively) are summarized in Table 4 . The results are based on 100,000 simulation steps using LHS mean simulation method.

Table 3. Moments and parameters of Lognormal distributions assigned to the random variable $\Delta_{L, m}$

\begin{tabular}{|c|c|c|c|}
\hline Sample & A_240/5 & B_480/9 & \\
\hline $\mathrm{n}$ & 58 & 30 & {$[\mathrm{pcs}]$} \\
\hline$\mu$ & 15.37 & 25.73 & {$[\mathrm{~mm}]$} \\
\hline$\sigma^{2}$ & 0.46 & 1.25 & {$[\mathrm{~mm}]$} \\
\hline $\mathrm{CoV}$ & 0.030 & 0.048 & {$[-]$} \\
\hline$\lambda$ & 2.73 & 3.24 & {$[-]$} \\
\hline$\zeta^{2}$ & 0.03 & 0.048 & {$[-]$} \\
\hline
\end{tabular}

Table 4. Interval estimation of mean and variance of stipulated bond shear stress $\tau$

\begin{tabular}{|c|c|c|c|}
\hline Sample: & A_240/5 & B_480/9 & \\
\hline $\mathrm{n}$ & 58 & 30 & {$[\mathrm{pcs}]$} \\
\hline$\mu$ & $\mathbf{1 2 9}$ & $\mathbf{9 6}$ & {$[\mathrm{kPa}]$} \\
\hline$\sigma^{2}$ & 0.0072 & 0.0034 & {$[\mathrm{kPa}]$} \\
\hline $\mathrm{CoV}$ & 0.056 & 0.035 & {$[-]$} \\
\hline $\begin{array}{c}\text { Confidence } \\
\text { interval for } \mu\end{array}$ & $\mathbf{1 2 7}$ & $\mathbf{9 5}$ & {$[\mathrm{kPa}]$} \\
\cline { 2 - 4 } & $\mathbf{1 3 1}$ & $\mathbf{9 8}$ & {$[\mathrm{kPa}]$} \\
\hline
\end{tabular}

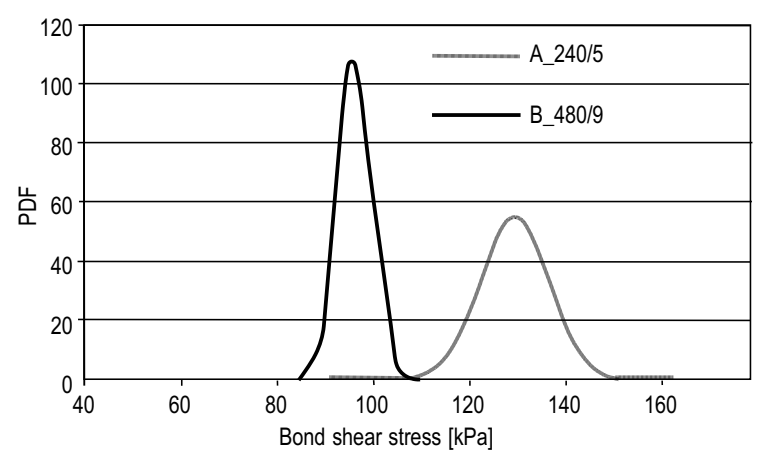

Fig. 5. Chart of PDF's of Lognormal distribution of random variable $\tau$

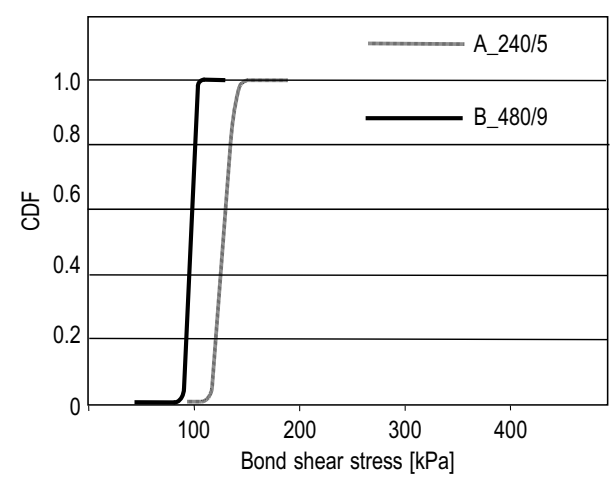

Fig. 6. Chart of CDF's of Lognormal distribution of random variable $\tau$ 


\section{Conclusions}

1. Objective of analysis was to determine the parameter of bond shear stress applicable in future design of anchors, in stiff to very stiff clays, based on formula:

$$
R=\left(\pi^{\star} d^{\star} L_{t b}\right)^{\star} \tau .
$$

2. The bond shear stress parameters determined by the process described above should be marked like stipulated. The reason is that the acceptance tests weren't executed until the pull out the anchor bond out of the soil. The limit state, defined like the failure of cohesion between the anchor bond and surrounding soil, wasn't been reached during the Acceptance test.

3. It should be noted, that two boundary situations can occur in cohesive soils during post-grouting of the bond of the anchor. Initial gravity grouting creates the body of bond, whose volume and shape are equal to the volume and shape of the borehole. Next post-grouting causes hydraulic destruction of soil structure. The net of micro cracks arises in a distance 10 to $20 \mathrm{~cm}$ from the surface of the bond body. The micro cracks are filled by the cement grout which, after its hardening, increases the bond capacity for anchor. However, the more adverse situation can occur, where the macro cracks arise in a distance to a several meters from the surface of the bond body. The macro cracks are connected with the bond by the thin layer of cement grout, and the effect of increasing the bond capacity for anchor by post-grouting decreases. (Klein, Mišove 1986). Hence, auxiliary parameter should be used in combination with the bond stress parameters determined in this study. The additional parameter is highest pressure measured during post-grouting process. Reaching identical value of grouting pressure as was the value observed in case of this study probably indicates the clamping of bond of anchor in surrounding soil in the same quality. The highest measured pressure was $2.5 \mathrm{MPa}$ for all anchors analysed in this case.

4. Values of bond shear stress recommended by various authors for design of ground anchors in stiff to very stiff clays differs relatively. Comparison of stipulated bond shear stress determined by this study to available recommendations is provided in Table 5.
Table 5. Comparison of study results - stipulated bond shear stress $\tau$, with values available in literature

\begin{tabular}{|l|c|c|}
\hline \multirow{2}{*}{\begin{tabular}{c}
\multirow{2}{*}{$\begin{array}{c}\text { Source of } \\
\text { recommended value }\end{array}$} \\
\cline { 2 - 3 }
\end{tabular}} & \multicolumn{2}{|c|}{ Recommended bond shear stress $\tau$} \\
\cline { 2 - 3 } & $30-70$ & Very stiff clay \\
\hline PTI (2004) & $40-60$ & $60-80$ \\
\hline Masopust (2004) & \multicolumn{2}{|c|}{$100-130$} \\
\hline Klein, Mišove (1986) & \multicolumn{2}{|c|}{$\mathbf{9 5 - 9 8 / 1 2 7 - 1 3 1}$} \\
\hline Study result & \multicolumn{2}{|c|}{} \\
\hline
\end{tabular}

\section{Acknowledgments}

This research was financially supported by the research project of Ministry of Industry and Trade No. FR-TI4/329 and by the Junior research grant of Brno University of Technology No. FAST-J-14-2438.

\section{References}

Baecher, G. B. 2003. Reliability and statistics in geotechnical engineering. Chichester: Wiley. $605 \mathrm{p}$.

Balšínková, V.; Hauser, J. 2010. Olomouc - Welnerova, IG průzkum. Brno: GEOSTAR, spol. s r.o. 18 p.

ČSN EN ISO 14688-2:2004. Geotechnický průzkum a zkoušeníPojmenování a zatřidování zemin - Část 2: Zásady pro zatřidování. Český normalizační institute ČNI, Praha, 2005.

ČSN EN 1537:2001. Provádění speciálních geotechnických prací - Injektované horninové kotvy. Český normalizační institut ČNI, Praha, 2001.

ČSN EN 1990:2004. Eurokód: Zásady navrhování konstrukcí. Český normalizační institut ČNI, Praha, 2004. 74 p.

ČSN EN ISO 22476-2:2005. Geotechnický průzkum a zkoušení: Terénní zkoušky - Část 2: Dynamická penetrační zkouška. Český normalizační institut ČNI. Praha, 2005.

D'Agostino, R.; Stephens, A. M. 1986. Goodness-of-fit techniques. New York: M. Dekker. 560 p.

Jones, D. A.; Turner, M. J. 1980. Load tests on post - grouted micropiles in London Clay, Ground Engineering 13(6): 47-53.

Koutková, H. 2004. Pravděpodobnost a matematická statistika MODUL GA03_M3 Základy teorie odhadu. Brno: Fast VUT Brno.

Klein, K.; Mišove, P. 1986. Únosnost' koreňa injektovanej kotvy v hornine, Inženýrské stavby 33(5): 251-255.

Kramer, H. 1978. Determination of the carrying capacity of ground anchors with the correlation and regression analysis. Revue francaise de géotechnique, Janvier.

Likeš, J.; Machek, J. 1981. Počet pravděpodobnosti. Praha: SNTL. $159 \mathrm{p}$.

Litteljohn, G. S. 1980. Design estimation of the ultimate loadholding capacity of ground anchors. Essex, England: Ground Eng. Found. Publ. 
Masopust, J. 2004. Speciální zakládání staveb. Brno: Akademické nakladatelství CERM. $141 \mathrm{p}$.

Novák, D.; Rusina, R.; Vořechovský, M. 2012a. FReET Program Documentation: Revision 10/2012, FReET version 1.5 Part 2 FReET M / A User Manual. Brno: Cervenka Consulting. $23 \mathrm{p}$.

Novák, D.; Vořechovský, M.; Rusina, R. 2012b. FReET Program Documentation: Revision 10/2012, FReET version 1.5 - Part 1 FReET Theory Manual. Brno: Cervenka Consulting. 52 p.

Pohl, C. 2011. Determination of characteristic soil values by statistical methods, in ISGR Geotechnical Safety and Risk. Bundesanstalt für Wasserbau, 427-434.

PTI. 2004. Recommendations for prestressed rock and soil anchors. 4 ed. Post - Tensioning Institute, Phoenix, 2004.
Sadílek, V.; Doležal, J.; Vořechovský, M. 2011. Řešené úlohy z oblasti spolehlivosti stavebních konstrukcí. Brno: Vysoké učení technické v Brně, Fakulta stavební. 80 p.

Štefaňák, J. 2013. Statistical analysis of data from acceptance tests of ground anchors, in Young scientist 2013: Proceedings of Annotations, 10-12 April 2013, Herl'any, Slovakia. Technical University of Košice, Faculty of Civil Engineering.

Vořechovský, M.; Miča, L.; Boštík, J. 2012. Posouzení únosnosti plošného základu: část 2 Ověření spolehlivosti návrhu plně pravděpodobnostní metodou, Stavební obzor 2012(2): 40-45.

Xanthakos, P. P. 1991. Ground anchors and anchored structures. New York: Wiley. 686 p.

http://dx.doi.org/10.1002/9780470172780

Jan ŠTEFǍ̌ÁK. PhD student at the Department of Geotechnics, Brno University of Technology, Faculty of Civil Engineering. Research interest: statistics and reliability in geotechnical engineering.

Lumír MIČA. Assoc. Prof. Dr at the Department of Geotechnics, Brno University of Technology, Faculty of Civil Engineering. Research interest: computer modelling of geotechnical structures, laboratory testing of geomaterials. 